\title{
New Horizons for Research on Bilingualism and Plurilingualism: A Focus on Languages of Immigration in Canada
}

\author{
Nuevos Horizontes para la Investigación sobre \\ Bilingualismo y Plurilingualismo: Enfocando en \\ las Lenguas Traídas por la Inmigración a Canada
}

\section{Nouveaux Horizons pour la Recherche sur le Bilinguisme et le Plurilinguisme : Accent sur les Langues de I'Immigration au Canada}

\author{
Yvonne Hébert, Yan Guo, and Martine Pellerin \\ University of Calgary
}

\section{ABSTRACT}

The appropriate education of immigrant students is the most significant issue of this global era. It is timely to expand new horizons for research on educational implications by creating a comprehensive corpus of research on theories and practices dealing with linguistic rights; policy options; types of programmes; structural change; implementation and engagement. Drawing from the extensive research on bilingualism and bilingual education, this paper proposes an expansion beyond official bilingualism to embrace plurilingual education. A possible research agenda is generated. Sets of research topics are formulated in each area of relevance to plurilingual education as the future of education in Canada.

Key words: bilingualism, plurilingualism, educational policy and bilingualism, educational programs, research agendas and plurilingualism.

\section{RESUMEN}

La educación apropiada para los estudiantes inmigrantes es el problema más significativo en esta era global. Es tiempo de abrir nuevos horizontes y crear un corpus comprensivo de investigación sobre las teorías y prácticas relacionadas a los derechos linguísticos, opciones en política educacional, tipos de programas, cambios estructurales, e implementación de políticas. Este artículo está basado en una exploración extensa de la literatura sobre bilingualismo y educación 
bilingua y propone que se vaya más allá del bilingualismo oficial para abrazar una educación plurilinguista. El artículo genera una agenda de investigación y agrupa tópicos de investigación en áreas relevantes para el desarrollo de una educación plurilinguista en Canadá, que es aquí propuesta como la dirección futura de la educación en Canadá.

Descriptores: bilingualismo, plurilingualismo, política educacional y bilingualismo, programas educacionales, agenda de investigación y plurilingualismo.

\section{RÉSUMÉ}

L'éducation propice des étudiants de l'immigration est la problématique la plus saillante de cette époque mondialisée. Le temps est venu d'ouvrir de nouveaux horizons pour la recherche sur les significations éducatives en créant un corpus de recherche compréhensif sur les théories et les pratiques découlant des droits linguistiques; les options de politiques; les modèles de programmes; le changement d'infrastructure; la mise en pratique et l'engagement. Basé sur la recherche préalable sur le bilinguisme et l'éducation bilingue, ce papier propose une expansion au-delà du bilinguisme officiel pour embrasser l'éducation plurilingue. Un agenda de recherche possible est proposé. Des ensembles pertinents de sujets de recherche sont formulés pour chaque domaine de l'éducation plurilingue en tant que l'avenir de l'éducation au Canada.

Mots-clés : bilinguisme, plurilinguisme, programme de recherche, politique linguistique.

\section{Language Education Issues and Globalisation}

$\mathrm{T}$ HE CONTEXT OF GLOBAL MIGRATION provides an opportunity to look ahead at the possible needs for research in ten to fifteen years from now. This would require advancing the field of study of bilingualism to plurilingualism in order to inform emerging policy and programme priorities. In this globalising context, we understand that the most pressing educational issue today is the under-education of immigrant children and youth for integration into host societies, as do Suárez-Orozco and Sattin. ${ }^{1}$ This became quite clear as the results of the Program for International Student Assessment (PISA) study shocked countries such as Germany and the United States who confronted their records of poorly educating children and youth of immigrant origins. In Canada, the provincial jurisdictions gloried in the very high ranking of its fifteen-year old population on all three PISA cycles to date as well as on the PIRLS, attributing their educational successes to excellent curriculum although the teachers see themselves making a difference. ${ }^{2}$ This however camouflaged the high dropout rate which includes recent adolescent arrivals in English-as-a-Second Language (ESL) programmes. Contributing to the dropout rate is the recent lowering of the legal age to work in the food and tourist industries to twelve years in Alberta. More generally, the results for immigrant youth reveal stark differences in achievement patterns. A profound alienation, anomie and anger of youth exist in many countries, for example, among the rioting French youth, as a consequence of unfavourable social and work life and its intersection with discriminatory schooling. ${ }^{3}$ This glaring failure is located in the context of globalisation, with its vital flux of migration from developing countries to wealthy cities in North America and Europe. ${ }^{4}$

The term, globalisation has two meanings. One refers to the emergence of a 'worldsystem,' a state of affairs which is already realised, at least in part. ${ }^{5}$ The other refers to the neo-liberal ideology that underlies the world system. A substantial redefinition of 
our societies, stemming from complex transformative phenomena that began in the mid-1970s, is at the centre of globalization and rests upon knowledge. ${ }^{6}$ Furthermore, these historical changes are undeniably inscribed in a political and economic dynamic of considerable magnitude, marked by the neo-liberal ideology. Linked to a quest for flexibility among large corporations, this ideology is actualised by the partition of work and the multiplication of practices of externalisation of work, delocalising the work in networks of factories, for example, in many other countries where labour is unorganized and poorly paid. While large corporations increase their profits and are a source of economic vitality, they are nevertheless the cause of the loss of many jobs, the lowering of working conditions, the multiplication of precarious employment, and the increase of social inequalities, all of which shake the foundations of the salaried workforce and have particularly nefarious consequences for youth and education. ${ }^{7}$

In accordance with this understanding, globalisation has impacted upon states' normative, instrumental and symbolic influences on collective identity formation, altering states' capacity "to provide a reference frame for individual and group identities, belongings, actions and interactions." ${ }^{8}$ This yields a new demographic, geographical and sociological 'space' or system, that is delocalised and that constitutes a specific level of economic, political, social, cultural, judicial and military activity, involving mobility and expansion. In this light, predictions of population growth indicate the importance of immigration to the future survival of this country. ${ }^{9}$

Research has focused on many dimensions of learning and teaching languages. It is however in the context of pervasive globalisation that new horizons arise, giving way to the fluid intersections of many peoples, languages, cultures, and identifications, all of which create new opportunities for life, education and research. Exploring this fluidity, our paper focuses on children's rights, policy and programme models, as well as teacher preparation, pedagogies and practices for plurilingual realities, drawing from Canadian and international perspectives and experiences. A fourth section dwells on capacity building for national and international research collaboration. In the ensuing discussion, we seek to anticipate what knowledge will be needed in the next ten to fifteen years and to identify relevant research topics.

\section{Children's Rights}

In order to address the need for a quality education for all learners including immigrant and refugee children and youth, an argument may be established for plurilingual education by turning to children's rights. The Convention on the Rights of the Child ${ }^{10}$ recognizes the right of the child to education in a manner consistent with the child's dignity, ${ }^{11}$ to an adequate standard of living for physical, mental, spiritual, moral and social development, ${ }^{12}$ to the development of the child's abilities to their fullest potential; to respect for human rights and fundamental freedoms; to respect for the child's parents; his or her own cultural identity, language and values, for the values of the country in which the child is living, from which he or she originated and for civilizations different from his or her own; and to preparation for responsible life 
in a free society in the spirit of understanding, peace, tolerance, equality and friendship among all peoples. ${ }^{13}$ For children of minority or indigenous origin, there is a right to be in community with others to enjoy their culture, to profess their religion and to use their language. ${ }^{14}$ All states except the USA and Somalia are signatory parties to this Convention.

This provides strong impetus for an argument for plurilingual education for children and youth of immigrant origins. Little research has been undertaken directly on the Convention, its implementation; and on its understanding and application among educational leaders, teachers and parents; on optimal models of rights education; and on the Convention's relevance and impact on schooling. ${ }^{15}$ Moreover, there is a paucity of policy research pertaining to the intersection of language, culture and identity on all levels: federal, provincial and local, an intersection of considerable interest given the UN Convention on the Rights of the Child.

Furthermore, research is needed linking the rights of the child more explicitly with country-based linguistic rights and policies for populations that are increasingly plurilingual. Research on the implementation of rights-based policies would consider program configurations and their interconnection with languages, cultures, territories, and belongings; implications of this population growth for teacher education, communication technology for language learning and teaching, assessment, parental and community engagement, necessary for evidence-based policy making, programme development and daily practice.

\section{Policy for Plurilingual Realities}

In light of ongoing global migration and substantial change in terms of linguistic and cultural diversity in Canada over time, such as recognition of the rights of self governance of Aboriginal people and Francophone rights of parental control of educational governance, Canada has gained a great deal of experience and insight into what is required for societal and educational support for linguistic diversity. Canada has developed policies and laws which establish a foundation for bilingualism and multiculturalism. For many decades, bilingualism in Canada referred to French and English, however, languages such as Chinese and Spanish are also offered in schools. ${ }^{16}$ In light of extensive Canadian experience, plurilingualism and plurilingual education can exist only if a sufficient policy and legal context are in place, just as Aboriginal and Francophone education in a minority context could only succeed with charter, legal, policy, and judicial support as well as research evidence. In almost all provinces and territories, Francophone parents have been obliged to go all the way to the Supreme Court to obtain their rights to the control and governance of their own schools, with arguments ranging from self-preservation of the group, safeguard of the individual's collective identity, assurance of completion of schooling, and voice and perspective in the curriculum. ${ }^{17}$ Only then, might Canadians have a civil society in which citizens and immigrants alike could interact comfortably in their own language and achieve self- and political efficacy.

The appropriate education for immigrant students is the most important issue 
of this era, yet it continues to be hotly debated. ${ }^{18}$ On one hand, most educators adopt an English-only policy in their classrooms, believing that immigrant students' native languages are actually hindering their learning in schools. They believe immigrant students need to shift to English as rapidly as possible, thus articulating assimilationist positions. Currently, multicultural policies in most jurisdictions are still in the compensatory and remedial approaches of previous decades. On the other hand, pluralists argue that in order to ensure equality of opportunity, the state must provide support for linguistic diversity. ${ }^{19}$ Further to that, advocates of language rights argue that national minorities (as opposed to those of immigrant minorities) have the same rights and entitlements as the majority group to the recognition, validation and use of their languages and cultures. ${ }^{20}$ This argument is extended to the recognition that an individual's right to use and learn his/her own native language is a basic human right. ${ }^{21}$ The UN Convention on the Rights of the Child supports this argument to develop the child to the fullest potential as detailed in articles 29 and 30 (see Appendix A). This provides strong impetus for an argument for plurilingual education for children and youth of immigrant, refugee, minority and indigenous origins.

A wide range of research shows social, cultural, educational, linguistic, and economic benefits of bilingual and plurilingualism for the individual and for the society as a whole. ${ }^{22}$ Bilinguals tend to perform better than monolinguals on cognitive tasks that call for divergent thinking, creative thinking, and problem solving, and they tend to demonstrate sophisticated levels of metalinguistic awareness, greater mental flexibility, openness and understanding of cultures, and communicative sensitivity than monolinguals. Promoting bilingualism and plurilingualism is not only beneficial for the individual but also for the nation. In a global world, Canada needs people who are competent in a variety of languages for social, cultural as well as economic reasons, i.e. for international business and economic growth.

Thus, there is a need for research on pluralist, integrated approaches to linguistic rights and language planning, policy development and implementation. Such research would expand upon research on official language bilingualism to encourage plurilingualism rather than linguistic assimilation, now termed integration, among immigrants. Future research needs to examine the opportunities for students to use multiple languages in their learning and the relationships between languages and the construction of multiple identifications. Long-term quantitative analyses of trajectories through the system are needed for all students including immigrant students. Additional issues focus on the definitions of categories, their compatibility across provinces, and access to these data.

The following topics arise for research now and in the near future to anticipate the need for new knowledge for all eventualities in the next ten to fifteen years:

- The linkages between policy and programme models;

- The suitability/adequacy of current and new models of linguistic rights and language planning for the contemporary and emergent needs of Canadians;

- The breadth of policy development, management and implementation for populations that are increasingly plurilingual; 
- The development of national policies for bilingual and plurilingual education beyond official bilingualism, as well as their implementation and management;

- The theoretical and practical ramifications of plurilingual schooling;

- The influence of political, cultural, economic, geographical and social factors upon educational policies and practices concerning bilingual and plurilingual education;

- The impact on educational systems of plurilingual education as the new norm; and

- The realities of plurilingual identifications among learners of immigrant origins.

\section{Policy Implementation}

Administrators are key players in any structural change in education. Yet, research shows considerable administrator resistance to systemic reform due in part to the dominant technical approach to administration rather than cultural constructivist perspectives. ${ }^{23}$ Future research is needed to examine how administrators create a welcoming environment for immigrant students. Moreover, research is needed to identify the best practices that support communicative, transcultural, and social interaction between immigrant and non-immigrant Canadians. ${ }^{24}$ Future research may address topics such as these:

- The establishment and maintenance of school climates that are supportive of minority languages and affirming of children's and adolescents' complex identifications;

- The ways and means with which administrators respect, support, integrate, and advocate on behalf of French and/or English as additional language education in schools;

- The contributions of administrators in the cultivation of language awareness, communicative sensitivity, and the provision of social inclusion for all new Canadian students;

- The discursive and interactive treatment afforded by staff members to immigrant students and parents, upon arrival and subsequent integration;

- The experience and strategies of administrators of minority backgrounds living their leadership in a dominant system; and

- The best practices for supporting relationships and networking between immigrant and non-immigrant students at school and beyond.

\section{Program Models for Plurilingual Realities}

Three broad types of program models now exist, ranging in their commitment to diversity from the least to most active, their link to models of citizenship, epistemological paradigms and ethical positions. Organising these according to notions of social justice and educational responses, we combine here typologies developed by Banks, Skutnabb-Kangas, McAndrew, and Crul. ${ }^{25}$ 


\section{Assimilative Models}

- The basic assimilative model insists on having the children and parents drop the mother tongue(s) as soon as possible. Education is provided only in the dominant language of the receiving country, with considerable pressure from school authorities as well as peers to change as rapidly as possible. ESL programming originated from within this model as a more efficient way of teaching and learning English.

This model assumes the inferiority of children and their parents, with their linguistic and cultural knowledge disregarded and discounted as possible resources for schooling. Assimilative policies and programs in education discourage students from maintaining their mother tongue. "While students may not be physically punished for speaking their mother tongue in the school, a strong message is communicated to children and youth of immigration, that if they want to be accepted by the teacher and society, they have to renounce any allegiance to their home language and culture." 26

\section{Remedial, Compensatory Models}

- Selective incorporation of elements pertaining to immigrant languages, cultures and religions in school activities, such as celebrations of festivals, foods, dance and other customs.

- Implementation of activities tailored to the needs and characteristics of learners of immigrant minorities from an equality of opportunity perspective.

- Implementation of programmes, such as English (or French) as a Second Language (ESL) to prepare learners of immigrant origins to enter the 'regular' school system. Framed by provincial curriculum setting clear goals and outcomes as well as the Canadian Language Benchmarks, schools in Canada offer second language instruction to immigrant learners in several configurations: preparatory programs prior to entry into mainstream schooling; school-based programs, with or without parental goals and involvement; and mainstream education with or without ESL support.

These are common types of practice found in various degrees and giving rise to little debate, regardless of the model of pluralism and citizenship. Most of the Canadian research on ESL (now termed English as an Additional Language) consists of single or multiple case studies which provide nuanced portraits of such programming. Those offering ESL prior to entrance into the mainstream without support of any kind are compensatory, remedial approaches, consistent with distributive forms of social justice. Viewed negatively within school and community contexts, ${ }^{27}$ these students are not seen as entitled to any academic rewards or resources, as per a distributive form of social justice. In other words, preparatory programs attempt to fix the learner, rather than fix the school to fit the learner. 


\section{Recognitive Models}

These models range from the acknowledgement of difference to the incorporation of multiple perspectives.

- Integration of specific immigrant-oriented content or perspective into the regular school curriculum so that differences and even conflicts over interpretation are acknowledged.

- Adaptation of norms and regulations relating to school life, such as anti-racism policies and procedures.

- Transformation of the curriculum in response to the demands of various organised communities, including national, ethnic and immigrant communities and pressure groups.

- Establishment of schools and educational systems usually for national minorities and sometimes for ethnic or immigrant groups.

To reflect contemporary and global plurilingual and multicultural realities, and to assure development to their fullest potential, students whose native language is neither English nor French need to have their cultural and linguistic knowledge recognized, respected, and integrated into school programming and social practice. In addition, global awareness and consciousness-raising are beneficial to develop deep transcultural understanding and interaction in a changing Canadian society. ${ }^{28}$ Differences based on language, culture, race, religion, and gender need to be recognized and respected. School as a learning system will similarly benefit from constructing wellfounded situated knowledge of immigrant learners in partnership with parents and communities. Doing so would build capacity to take multiple perspectives as lived social practice and to successfully provide meaningful education for the current and incoming populations. In this way, Canadian schools would prepare responsible citizens to participate, deliberate, and engage in civil society for the common good.

Research is needed on such models of schooling, on factors of success for first-and second-generation children and youth, as well as on the interconnections between language, culture, space or territorial attachments, and civic and political belongings. Possible future research topics to be explored include the following:

- The impact of various program configurations, ranging from assimilationist models to remedial, compensatory to recognitive models, upon learners' identities, strategies for learning and integration into Canadian society;

- Various strategies for recruitment, selection, and retention to facilitate the creation of a diverse teaching force;

- Curriculum needed to reflect the multicultural and plurilingual reality; and

- The challenges and opportunities for the integration of interdisciplinary approaches to curriculum design and delivery, weaving in new ideas in social studies, language, citizenship education, and global awareness.

The linkage between rights, policies, and programmes are particularly salient. ${ }^{29}$ Research will reveal the interconnections between the many players and factors that 
impinge upon the appropriate education of immigrant and refugee children and youth. These young people are an essential part of the Canada of the future, and the educational system must prepare to meet their needs and to make possible their smooth and sophisticated integration.

\section{Preparation, Pedagogies and Practices for Plurilingual Realities}

Students speaking many languages and living many cultures are increasing in number in Canadian schools. Teachers, however, are mostly female, white, middle-class and monolingual. ${ }^{30}$ This mismatch between students and teachers has implications for research on appropriate teacher education, integration of communication technology in language learning and teaching, assessment, parental and community engagement.

\section{Teacher Preparation, Professional Development, and Graduate Education}

Teacher education in this context must be reconceptualised and research is needed to provide evidence for decision making and informed practices. To address the cultural incongruence between teachers and students, three goals have been identified: a) program efforts to recruit teachers from culturally and linguistically diverse communities; b) program curriculum designed to develop the attitudes, awareness, and multicultural knowledge base of all pre-service teachers; ${ }^{31}$ and c) inclusion of language methodologies for all teachers to assure the appropriate education of plurilingual learners. To actualize the first goal, greater representation of multicultural and plurilingual individuals as teachers, administrators, and clerical staff is essential for the success of immigrant students. Further to the second and third goals, in spite of the long-established recognition that all teachers are second language teachers, ${ }^{32}$ little action has been taken to systematically assure their preparation; the time has come.

A greater knowledge of language teaching and learning among teachers is needed so that an integrated approach to ESL/FSL, rather than pull-out, can be adopted in Canadian schools. In the plurilingual education context, every teacher is a language teacher, which means that the second language is integrated into every subject. An alternative approach to integration has the ESL/FSL teacher working side by side with the content teacher, more feasible at the elementary level. At high school level, there is collaboration between content teachers and ESL/FSL teachers which leads to an emphasis on writing and support for written assignments. In such approaches, the ESL classroom serves as a centre to receive and orient new students. Subsequently, these students are mainstreamed as soon as possible where there occurs a rich language-learning environment where subject matter and language are taught simultaneously. Such practices and program reconfigurations could facilitate the emergence of new pedagogical approaches supporting curriculum and classroom change. Such transformations reflect philosophical and theoretical frameworks that aim to promote twenty-first century learning skills such as inquiry with use of communication 
technology as well as to explore new approaches such as ecology of language. ${ }^{33}$ These transformations would also need to address issues such as who counts as knower, whose knowledge counts, and how knower and knowledge interact in contexts.

Professional development and graduate education also need to keep pace to develop and sustain greater understanding of the impact of globalisation on educators and schools, especially with respect to languages, cultures, what counts as knowledge, and who decides. Moreover, teachers can learn an additional language themselves in order to build their language awareness and communicative sensitivity. Scholarships available from provincial ministries of education for teachers to pursue graduate studies in second language education could be extended to include ESL teachers.

To meet comprehensive future needs, possible research topics include the following:

- Development of appropriate and innovative theoretical frameworks for initial and continuing teacher education;

- The provision of services by pre-service and practicing teachers to meet the needs of culturally and linguistically diverse communities;

- Best practices for the preparation of pre-service and practicing teachers for the effective teaching of dominant and additional languages; as well as effective language acquisition;

- The impact of global awareness upon teachers and their reflection upon their practice;

- The impact of teaching practices upon the transfer of global awareness, consciousness-raising, and transcultural understanding to their classrooms;

- Appropriate means for addressing teacher resistance to diversity;

- New paradigms which would best serve to respect linguistic diversity and promote plurilingual learning;

- Best practices for the accommodation of plurilingual students in classrooms;

- Effective strategies for the inclusion of many languages in classroom instruction by English-only or French-only teachers;

- The lessons to be learned from Canadian Immersion programs, reputed nationally and internationally for their effectiveness;

- The integration of explicit language instruction into discipline-based learning;

- The overlap and combination of first/dominant and second/additional language instructional strategies and techniques in daily practice;

- The integration of literacy in subject competencies;

- Teacher-student positionings in terms of majority/minority status, use of various languages, and power relations;

- The balancing of students' cultural identifications, multiple languages, and school roles in various contexts; and

- The effectiveness of various program configurations in terms of student learning, parental satisfaction, and community capacity moving towards institutional completeness. 


\section{Integrating Technology and Language Learning}

In the twenty-first century, students live in a world of technology and media which allows them easy access to greater information, communication, and collaboration without temporal and spatial limitations, for example in the virtual world such as "Second Life." Such usage allows for international networking, plurilingual communication, transcultural understanding and the development of multiple perspectives of the world. Creating personalised blogs and participating in joint educational projects is an example of connecting students digitally in migrant and receiving communities. This could serve to nurture global consciousness, that is, a mindful way of being in the world today. ${ }^{34}$ This suggests that students have already moved from a monolingual to a plurilingual paradigm for learning and living, a move that schools would do well to emulate. Agreements between national, regional or local governments would be needed to initiate and support such projects. To succeed would be to enrich and build a global community of peaceful relations. Thus, research is needed on topics such as these:

- The development of new pedagogies that integrate technology in insightful, effective and satisfying ways;

- The influence of new pedagogies upon one another, for example, blended approaches that involve face-to-face teaching with integration of online technology such as using authentic language materials via video, podcasting, YouTube, blogging, wiki, Facebook for synchronous and asynchronous communications; and

- The adoption of new pedagogies integrating language learning and technology, by teachers and by learners.

\section{Assessing Language Proficiency}

Further research on assessment models and practices is needed with respect to language proficiency in the plurilingual classroom. The Canadian educational system is highly decentralized, given provincial and territorial responsibility, and without a national office or ministry of education, there is a need for research collaboration to develop a common framework of reference for languages in Canada. Such a framework could be used as a point of reference on a voluntary basis, by formal education systems, employers and cultural institutions across Canada and beyond into the international arena. ${ }^{35}$

Some topics arise for assessment research:

- The relevance of the Common European Framework of Reference for Languages (CEFR) for the Canadian context, given its official bilingualism and plurilingual realities;

- The realities of language assessment, given various program models, and the weight given to guidelines and testing;

- Definitional dimensions of 'language proficiency' in a multicultural and plurilingual classroom context, especially with respect to second/additional languages; 
- The measurement of achievement and performance of language learning within classrooms, its criteria, type, timing, method and administration;

- The impact of systemic language testing on learners, teachers and parents; and

- The possible cultural biases in the development of appropriate language assessment tools.

\section{Parental Knowledge and Community Engagement Practices}

One of the most important factors that contributes to student success is the school's ability to bridge the gap(s) between the school and its various communities with effective partnerships in student learning. Currently, immigrant parent involvement goes unrecognized, possibly unwanted because it does not correspond to the norm of white, middle-class parents. ${ }^{36}$ Immigrant parents often feel excluded from decision making that could improve their children's learning. ${ }^{37}$

At issue here are the nature of school-parent-community relationships; what counts as school knowledge and effective parenting; appropriate sociolinguistic discursive styles and transcultural interactions; and contemporary school demands of particular parental roles and home support. Moreover, teachers and students do not necessarily share a common community base as they typically live in different neighbourhoods especially in large urban areas. Possible research topics to generate future knowledge include the following:

- The recognition and utilisation of immigrant parental knowledge in schools;

- The immigrant parents' contributions to their children's successes;

- The value assigned by teachers to immigrant parents' unique ways of participation in their children's education; and

- Teachers' communications with parents from diverse backgrounds; as well as collaboration between teachers and immigrant parents to improve student learning.

\section{Capacity-Building for National and International Research Collaboration}

Capacity-building is essential to assure successful implementation of the research agenda discussed here. We understand this to include networking between individuals, research centres and universities. Particular attention could be given to both longterm and new networks, thus bringing together experience and ingenuity. Many individual Canadian researchers have extensive connections and international research experiences. It makes sense to capitalize on this experience through institutes that could facilitate the management and organization of collaborative national projects focusing on issues relevant to language education. Leadership could be taken, for example, by the Canadian Institute for Research on Linguistic Minorities, University of Moncton; Official Languages and Bilingualism Institute, University of Ottawa; Modern Language Centre and Centre for Research on Francophone Education in Ontario, both at University of Toronto; Language Research Centre, University of 
Calgary; as well as by clusters of strong researchers in several Canadian universities, with pre-existing experiences with inter-university research projects as well as networking at major conferences in the field.

The time has come to take more systematic and comprehensive approaches in which researchers gather to scope out the research needs (to which this paper makes a contribution), take up responsibilities for particular topics, and arrange for further collaboration. Basic to networking is team compatibility which involves shared understandings of research concepts, methodology, and instrumentation; respect of intellectual property rights; and joint planning for the development of an effective system for data sharing and dissemination. Further to this, skilful use of exploratory, cumulative, conciliatory discourses is necessary to take up matters of dispute creatively so as to come to degrees of clarifications and new common understandings.

Seasoned researchers are likely to have developed a fine understanding of what is involved in sharing knowledge and working within shared infrastructures. Nonetheless, it is our experience that such matters are to be discussed explicitly before the onset of a project. Similarly, issues relating to ethics and intellectual property rights are subject to the standing policies of the institutions involved. Care needs to be taken that these policies are not in conflict with one another and that adequate coverage is provided for issues likely to arise in inter-institutional projects.

Within each university and language research centre, the researchers in question identify their strengths and interests, meld this into larger institutional and national collaborations, and assure consistency with institutional research priorities. To sustain the collaboration, provisions are needed for sharing data and results, planning dissemination such as further conferences and publications. Thus, shared infrastructures for success include blended communication technology for video-conference, digital telephony, as well as face-to-face meetings, for archiving and data access, for synchronous and asynchronous exchanges.

Further to this, educational statistical systems which track student progress through the years need further development so as to gather and make readily available comparable data in all jurisdictions, to better inform policy, planning, programs, and research. Currently, most provincial systems for data gathering on student progress and trajectories vary greatly and are not compatible with one another. Moreover, as mentioned previously in the section on policy, capacity-building to assure access to provincial data systems for research purposes is urgently needed. ${ }^{38}$

Finally, it must not be forgotten that large sums of funding are needed from international and Canadian sources, specifically targeted for bilingual and plurilingual research and networking. Within such funding, there are key issues to be dealt with such as appropriateness and relevance of contexts for knowledge making, graduate student mobility and formation, and the impact of the language of study.

\section{Conclusion}

Reflecting on our original purpose to explore new horizons for research on bilingualism and plurilingualism, we offer here as conclusion, a succinct statement of 
the proposed research program. In the context of globalization, with its vital flux of migration from developing countries to wealthy cities, the most pressing educational issue today is the under-education of immigrant children and youth for integration into host societies. Of fundamental importance is the link between children's rights and an education that is both appropriate and adequate. This necessitates policy research pertaining to the intersection of language, culture and identity on all levels. Future policy research could focus on linkages between policy, programme models and their implementation, with respect to the use of children's many languages for their learning, and identification. Further to such policy research, additional studies are needed on appropriate teacher education, integration of communication technology in language learning and teaching, assessment, parental and community engagement. To accomplish these research goals, capacity must be built so as to facilitate the networking, conceptualization, organization, and management of collaborative national and international projects. There is a major role here for existing research institutes, centres, and strong clusters of researchers to take leadership and assure coverage of knowledge needs for tomorrow.

\section{Acknowledgements}

This paper originated in notes prepared by Y. Hébert for a horizon-scanning invitational workshop of the European Science Foundation, Standing Committee for the Humanities, on the topic of 'New Perspectives for Research into Bilingualism/ Multilingualism', held in Stockholm, Sweden, December 6-7, 2007. Yan Guo and Martine Pellerin, among others, participated in preliminary conversations on the topic.

\section{Notes}

1. M.M. Suárez-Orozco and C. Sattin, "Introduction: Learning in the Global Era", in Learning in the Global Era: International Perspectives on Globalization and Education, ed. M. M. Suárez-Orozco (Berkeley: University of California Press, 2007),1-43.

2. Yvonne Hébert, D. G. Hatt, and M. Farrell, "Educational Success in Alberta Schools: From Policy to Practices to Outcomes: Preliminary Research Findings", Presentation at the annual conference of the Canadian Society for the Study of Education, May 28-31, 2005, London, $\mathrm{ON}$.

3. B. Charlot, Le rapport au savoir en milieu populaire: Une recherche dans les lycées professionnels de banlieue. (Paris: Anthropos, 1999); Yvonne Hébert, "Youth in Plural Cities, Multiculturalism and Citizenship: Policy Challenges and Opportunities", Synthesis Paper for a Panel on Engaging Ethno-cultural Minority Youth in the Practice of Citizenship: Policy Challenges and Opportunities in Australia, Canada, and France, organized by Canadian Heritage/Patrimoine Canada, at the International Metropolis Conference, October 1-6, 2006 in Lisbon, Portugal.

4. M.M. Suárez-Orozco and C. Sattin, Introduction.

5. I. Wallerstein, The Modern World System: Capitalist Agriculture and the Origins of the European World Economy in the Sixteenth Century (New York: Academic Press, 1997). 
6. Nuala Beck, Shifting Gears: Thriving in the New Economy, (Toronto: Harper-Collins Publishers, 1992); D. Mercure, Une société-monde? dans D. Mercure (Dir.,), Une sociétémonde? Les dynamiques sociales de la mondialisation, (Sainte-Foy: Les Presses de l'Université Laval et DeBoeck, 2001), 9-16.

7. Yvonne Hébert, "Localism and Globalism: Issues of Social Capital and Transculturation for Youth in Plural Cities", Paper and PPT presented at the International Workshop, Knowledge Transfer and Policy Development: Experiences from China and Canada, August 28-29, 2006 at the University of Saskatchewan, Canada; Mercure, D., Une sociétémonde?; Naomi Klein, No Logo: Taking aim at the Brand Bullies, (Toronto: Vintage Canada, 2000).

8. H.G. Sicakkan, "How is a Diverse European Society Possible? An Exploration into New Public Spaces in Six European Countries.” AMID Working Paper Series 46, International Migration and Ethnic Migration Research Unit, Center for Development Studies, University of Bergen, Norway, 2005: 5.

9. Statistics Canada, Population Projections of Visible Minority Groups, Canada, Provinces and Regions 2001-2017 (Ottawa: Statistics Canada, 2005).

10. United Nations, Convention on the Rights of the Child. Office of the High Commissioner for Human Rights, http://www.unhchr.ch/html/menu3/b/k2crc.htm (Accessed January 20, 2008).

11. Ibid., Article 28.

12. Ibid., Article 27.

13. Ibid., Article 29.

14. Ibid., Article 30.

15. For example see Yvonne Hébert, "On the Importance of Language to the Preparation of Citizens: Educators' Perceptions of the Integration of Immigrant Youth", Proceedings of the First Annual Conference of the Journal of Citizenship Teaching and Learning, 2005, http://www.citized.info/index.asp?strand=6\&r_menu=conferences_2005; R.B. Howe and K. Covell, Empowering Children: Children's Rights Education as a Pathway to Citizenship (Toronto: University of Toronto Press, 2005); E. Verhellen, "Children's Rights and Education", in Citizenship and Democracy in Schools: Diversity, Identity, Equality, ed. Audrey Osler (Stoke on Trent, UK and Sterling, USA: Trentham Books, 2000), 33-43; D. Archard, Children: Rights and Childhood (New York: Routledge, 1993).

16. J.Z. Wu, "Bilingual Education in Western Canada and Chinese Language Minority Students' Self Perceptions of their Citizenship and Ethnicity." Canadian and International Education, 34, no. 1(2005): 23-30,

17. P. Foucher, «Les droits scolaires des minorités linguistiques: le système judiciaire et le système scolaire ". Actes du colloque pancanadien sur la recherche en éducation en milieu francophone minoritaire: Bilan et prospectives (2000), http://www.acelf.ca/liens/crde/ articles/04-foucher.html (Accessed January 28. 2008).

18. M.M. Suárez-Orozco and C. Sattin, Introduction.

19. W. Kymlicka and A. Patten, ed. Language Rights and Political Theory (New York: Oxford University Press, 2003); T. Ricento, ed. An Introduction to Language Policy: Theory and Method (Malden, MA: Blackwell Publishing Ltd., 2006).

20. S. May, Critical Multiculturalism: Rethinking Multicultural and Antiracist Education (Levittown, PA: Routledge Falmer, 1999). 
21. T. Skutnabb-Kangas, "Language Policy and Linguistic Human Rights", in $A n$ Introduction to Language Policy: Theory and Method, ed. T. Ricento (Malden, MA: Blackwell Publishing Ltd., 2006), 273-91.

22. C. Baker, Foundations of Bilingual Education and Bilingualism ( $3^{\text {rd }}$ Edition), (Clevedon: Multilingual Matters, 2001); P. Chow and J. Cummins, "Valuing Multilingual and Multicultural Approaches to Learning", in Multilingual Education in Practice, ed. S.R. Schecter and J. Cummins (Portsmouth, NH: Heinemann, 2003), 32-61; J. Cummins, "Instructional Conditions for Trilingual Development", International Journal of Bilingual Education and Bilingualism, 4, no. 1 ( 2001): 61-75; D. Dagenais and C. Berron, "Promoting Multilingualism through French Immersion and Language Maintenance in Three Immigrant Families", Language, Culture and Curriculum, 14 (2001): 142-55.

23. C. Shields, "Why is there such a backlash to social justice?" Paper presented at the annual CSSE Conference, May 26-29, 2007 in Saskatoon.

24. R. Sussmuth, "On the need for teaching intercultural skills: Challenges for education in a globalizing world", in Learning in the Global Era: ed. M.M. Suárez-Orozco 195-212.

25. J. Banks, Multiethnic Education: Theory and Practice, $2^{\text {nd }}$ ed. (Boston: Allyn \& Bacon, 1988); T. Skutnabb-Kangas, Bilingualism or Not: The Education of Minorities, (Clevedon, UK: Multilingual Matters, 1981); M. McAndrew, "The Education of Immigrant Students in a Globalized World: Policy Debates in Comparative Perspective", in Learning in the Global Era: ed. M.M. Suárez-Orozco, 232-55; M. Crul, "Pathways to Success for the Children of Immigrants" (Washington, DC: The Transatlantic Task Force on Immigration and Integration, Migration Policy Institute/Bertelsmann Stiftung, 2007).

26. J. Cummins, Language, Power, and Pedagogy. Bilingual Children in the Crossfire. (Clevedon, England: Multilingual Matters, 2000).

27. Yan Guo, "Multiple Perspectives of Chinese Immigrant Parents and Canadian Teachers on ESL Learning in Schools", Diaspora, Indigenous, and Minority Education, 1, no. 1 (2007): 43-64.

28. D. Hoerder, Yvonne Hébert, and I. Schmitt, ed., Negotiating Transcultural Lives: Belongings and Social Capital among Youth in Comparative Perspective, (Toronto: University of Toronto Press, 2006).

29. Yvonne Hébert, "Integration via Education: The Education of Immigrant Children and Adolescents in Canada", Presentation Notes for the International Symposium on Integration and Education in the $21^{\text {st }}$ Century - a Challenge for Public Private Partnerships, October 16-17, 2007 in Berlin, Germany.

30. H. Hodgkinson, "Demographics and Teacher Education: An Overview"' Journal of Teacher Education, 53, no. 2, (2002):102-5.

31. C.E. Sleeter, "Preparing Teachers for Culturally Diverse Schools: Research and the Overwhelming Presence of Whiteness", Journal of Teacher Education, 52, no. 2, (2001):94106.

32. F. Genesee, "All Teachers are Second Language Teachers, Canadian Modern Language Review, 50 (1993): 47-53.

33. L. van Lier, The Ecology and Semiotics of Language Learning: A Sociocultural Perspective, (Norwell, MA: Kluwer Academic Publishers, 2004).

34. For example see V.B. Mansilla and H. Gardner, "From Teaching Globalization to Nurturing Global Consciousness" in Learning in the Global Era:, ed. M.M. Suárez-Orozco, 47-66. 
35. Canadian Heritage, "Proposal for a Common Framework of Reference for Languages for Canada”, (2006), http://www.canadianheritage.gc.ca/progs/lo-ol/pubs/new-nouvelles_ perspectives/tdm_e.cfm (Accessed April 22, 2008).

36. Yan Guo, Multiple Perspectives; A. Lareau, Unequal Childhoods: Class, Race, and Family Life, (Berkeley, CA: University of California Press, 2003).

37. J.K. Bernhard, M. Freire, V. Pacini-Ketchabaw, and V. Villanueva, "A Latin American Parents' Group Participates in their Children's Schooling: Parent Involvement Reconsidered", Canadian Ethnic Studies Journal, 30, no. 3, (1998):77-98.

38. M. McAndrew, P. Anisef, J.-G. Blais, C. Ungerleider, and R. Sweet. Academic Performance and Educational Mobility of Youth of Immigrant Origin in Canada: What Can We Learn from Provincial Data Banks? Final Report. (Ottawa: Citizenship and Immigration, 2004).

\section{References}

Bastarache, M. (Dir.). Les droits linguistiques au Canada. Montréal: Les Éditions Yvon Blais Inc., 1986.

Beauchamp, P. Parents Give ESL Programs Poor Grades in Survey. Calgary Herald, Sunday, October 7, 2007, p. B4.

Bernhard, J. K., and Freire, M. What is my Child Learning at School? Culturally Contested Issues of Latin American Children and Families. Canadian Ethnic Studies Journal 3, no. 3 (1999): $72-94$.

Bernhard, J. K., Freire, M., Torres, F., and Nirdosh, S. Latin Americans in a Canadian Primary School: Perspectives of Parents, Teachers, and Children on Cultural Identity and Academic Achievement. Journal of Regional Studies 19, no. 3 (1998), 217-36.

Castellano, M., L. Lahache and Davis, L. eds. Aboriginal Peoples in Canada. Vancouver: UBC Press, 2000.

Christensen, G. and Stanat, P. Language Policies and Practices for Helping Immigrants and Second-Generation Students Succeed,.Washington, D.C.: The Transatlantic Task Force on Immigration and Integration, Migration Policy Institute/Bertelsmann Stiftung, 2007

Churchill, S. The Education of Linguistic and Cultural Minorities in the OECD Countries. Clevedon, England: Multilingual Matters Ltd., 1986.

Crul, M. "The Integration of Immigrant Youth.” In Suárez-Orozco, M.M. ed. Learning in the Global Era: International Perspectives on Globalization and Education. Berkeley: University of California Press, 2007, 213-31.

Dewing, M. and Leman, M. Canadian Multiculturalism. Ottawa: Library of Parliament, Government of Canada, 2006. http://www.parl.gc.ca/information/library/ PRBpubs/936-e.pdf

Gale, T. and Densmore, K. Just Schooling: Explorations in the Cultural Politics of Teaching, Buckingham, UK and Philadelphia: Open University Press, 2000.

Gillborn, D. Racism and Antiracism in Real Schools: Theory, Policy, Practices. Buckingham, UK: Open University Press, 1995.

Guo, Yan. "Why Didn't They Show Up?": Rethinking ESL Parent Involvement in K-12 Education. TESL Canada Journal, 24, no.1 (2006): 80-95.

Hébert, Yvonne, Neary, S., Lee, J.W., and Goddard, T. Academic Performance and Educational Mobility of Youth of Immigrant Origin In Canada: What Can We Learn from the Alberta Provincial Data Banks? Final Report. Ottawa: Citizenship and Immigration Canada, 2005.

Kouritzin, S. Programs, Plans and Practices in Schools with Reputations for ESL Student Success. Canadian Modern Language Review 60, no. 4 (2004): 481-99. 
Lambert, W. E. Culture and Language as Factors in Learning and Education. In Wolfgang, A. ed. Education of Immigrant Students, Issues and Answers. Ontario Institute for Studies in Education, 1975.

Lee, W. J. and Hébert, Yvonne. The Meaning of Being Canadian: A Comparison between Youth of Immigrant and Canadian Origins. Canadian Journal of Education 29, no. 2 (2006): 497-520.

Leibowitz, A.H. The Bilingual Education Act: A Legislative Analysis. Rosslyn, VA: National Clearinghouse for Bilingual Education, 1980.

Leseman, P. Early Education for Immigrant Children. The Transatlantic Task Force on Immigration and Integration, Migration Policy Institute/Bertelsmann Stiftung, 2007.

Letourneau, J. and Bernard, R. La question identitaire au Canada francophone: Récits, parcours, enjeux, hors-lieux. Sainte-Foy: Les Presses de l'Université Laval, 1994.

Lévesque, S. "Becoming Citizens: High School Students and Citizenship in British Columbia and Québec." Encounters on Education 4, (fall 2003): 107-126.

May, S. "Language Policy and Minority Rights." In Ricento, T. ed. An Introduction to Language Policy: Theory and Method. Malden, MA: Blackwell Publishing Ltd., 2006, 255-72.

May, S. Critical Multiculturalism: Rethinking Multicultural and Antiracist Education. Levittown, PA: RoutledgeFalmer, 1999.

McAndrew, M., Ciceri, C. and Jacquet, M. La prise en compte de la diversité culturelle et religieuse dans les normes et pratiques de gestion des établissements scolaires: Une étude exploratoire dans cinq provinces canadiennes. Revue des sciences de l'éducation 23, no. 1 (1997): 209-32.

Organisation for Economic Co-operation and Development. L'éducation multiculturelle. Paris: Centre pour l'innovation et la recherche en éducation, 1987.

Packer, J. "Ethnicity, Civil Society and Public Policy: Minority Inclusion in Democratic Governance Strategies." Presentation at the biennial conference of the Canadian Ethnic Studies Association (CESA). Winnipeg, September, 27-30, 2007.

Pagé, M. Courants d'idées actuels en éducation des clientèles scolaires multiethniques. Avec la collaboration de Provencher, J. et Ramirez, D. Québec: Conseil supérieur de l'éducation, 1993.

Roessingh, H. "Effective High School ESL programs: A Synthesis and Meta-analysis." Canadian Modern Language Review 60, no. 5 (2004): 611-36.

Roessingh, H. "Variability of ESL Learners' Acquisition of Cognitive Academic Language Proficiency: What Can We Learn from Achievement Measures?” TESL Canada Journal 21, no. 1 (2003): 1-21.

Swain, M. and Lapkin, S. "The Evolving Sociopolitical Context of Immersion Education in Canada: Some Implications for Program Development." International Journal of Applied Linguistics 15, no. 2 (2005): 169-86. 